\title{
Mechanical soy bean washing improves the performance of tempe crafters
}

\author{
Anizar Anizar ${ }^{*}$, Zainul Bahri Torong ${ }^{2}$ \\ ${ }^{1}$ Departemen Teknik Industri, Fakultas Teknik, Universitas Sumatera Utara \\ ${ }^{2}$ Departemen Akuntansi, Fakultas Ekonomi dan Bisnis, Universitas Sumatera Utara \\ *Email : anizar_usu@usu.ac.id
}

\begin{abstract}
The business of making tempe every day processes $50 \mathrm{~kg}$ of soybeans into tempeh done manually with 4 craftsmen. But the washing of soybeans is one of the most tiring activities because the crafters have to lift buckets filled with soybeans and water so that the weight of the bucket is quite heavy. The process of washing soybeans starts from the step of pouring $10 \mathrm{~kg}$ of soybeans into a bucket, giving water, stirring, lifting the bucket to pouring the water in the bucket. Washing the soybeans until clean is done by the craftsman continuously up to 5 times. Processing $50 \mathrm{~kg}$ of soybeans causes the craftsman to carry out the process of washing soybeans 25 times each day. The craftsman complains of back pain and both arms and sometimes the craftsman does not come to work if the pain is unbearable. Utilization of soybean washing tools can reduce the washing time so that the process can be completed more quickly and the crafters do not experience pain complaints. Mechanical soybean washing causes shorter washing time for soybeans, faster work, cleaner soybeans and crafters free from complaints of back pain.
\end{abstract}

\section{Keyword: Soy Bean Washer, Mechanical, Performance, Tempe}

\begin{abstract}
Abstrak
Usaha pembuatan tempe setiap harinya mengolah $50 \mathrm{~kg}$ kacang kedelai menjadi tempe dilakukan secara manual dengan 4 orang perajin. Namun kegiatan pencucian kacang kedelai merupakan salah satu kegiatan yang paling melelahkan karena perajin harus mengangkat ember berisi kacang kedelai dan air sehingga bobot ember cukup berat. Proses pencucian kacang kedelai dimulai dari tahapan penuangan $10 \mathrm{~kg}$ kacang kedelai ke dalam ember, pemberian air, pengadukan, mengangkat ember hingga menuangkan air yang ada di dalam ember. Kegiatan pencucian kacang kedelai hingga bersih tersebut dilakukan perajin secara terus menerus hingga 5 kali. Pengolahan $50 \mathrm{~kg}$ kacang kedelai menyebabkan perajin harus melakukan proses pencucian kacang kedelai sebanyak 25 kali setiap harinya. Perajin mengeluhkan sakit pinggang dan kedua lengan dan terkadang perajin tidak masuk kerja jika sakit tidak tertahankan. Pemanfaatan alat pencuci kacang kedelai dapat mengurangi waktu pencucian sehingga proses dapat selesai lebih cepat dan perajin tidak mengalami keluhan sakit. Pencuci kacang kedelai mekanis menyebabkan waktu pencucian kacang kedelai menjadi lebih singkat, pekerjaan lebih cepat, kacang kedelai lebih bersih dan perajin terbebas dari keluhan sakit pinggang.
\end{abstract}

Kata Kunci : Pencuci kacang kedelai, Mekanis, Kinerja, Tempe

\section{PENDAHULUAN}

\subsection{Latar Belakang}

Usaha kedelai dikenal di Indonesia sejak abad ke-17 yang dibudidayakan sebagai tanaman makanan dan pupuk hijau. Hingga saat ini kedelai di Indonesia banyak ditanam di dataran rendah yang tidak banyak mengandung air, misalnya di pesisir Utara Jawa Timur, Jawa Tengah, Jawa Barat, Gorontalo (Sulawesi Utara), Sulawesi Tenggara dan Lampung serta Selatan dan Bali (Fauzi \& Puspitawati, 2018). Dalam kehidupan masyarakat Indonesia, kedelai telah dikenal sejak lama sebagai salah satu tanaman sumber protein nabati dengan kandungan $39-41 \%$ yang diolah menjadi bahan makanan, minuman serta penyedap cita rasa makanan, misalnya yang sangat terkenal adalah tempe, tahu, kecap, tauco dan tauge. Kedelai bahkan diolah secara modern menjadi susu dan 
minuman sari kedelai yang dikemas dalam karton khusus atau botolan. Selain itu kedelai berperan penting dalam beberapa kegiatan industri dan peternakan (Nainggolan, 2014).

Mitra transformasi sektor pertanian ke sektor industri bagi negara sedang berkembang seperti Indonesia ini, tidaklah dapat dihindarkan. Indonesia mulai beranjak dari negara agraris menuju negara industri yang maju sehingga peran sektor pertanian masih tetap mewarnai kemajuan di sektor industri sehingga diperlukan suatu kondisi struktur ekonomi yang seimbang antara bidang industri yang kuat dengan dukungan pertanian yang tangguh (Romli, Hutagaol, \& Priyarsono, 2016). Peranan industri kecil terhadap roda perekonomian suatu negara sangat besar. Di Indonesia, 99\% dari total unit usaha yang mandiri merupakan unit usaha kecil namun kontribusinya terhadap Produk Domestik Bruto (PDB) hanya 14\% saja. Hal ini menjadi suatu tantangan bagi para pengusaha kecil untuk lebih meningkatkan. Salah satu usaha kecil yang potensial dikembangkan adalah industri pembuatan tahu dan tempe. Kalau usaha itu dijalankan serius pasti akan menguntungkan karena konsumen tahu dan tempe sangat luas yang mencakup semua strata sosial. Tahu dan tempe tidak hanya dikonsumsi oleh masyarakat kelas bawah dan menengah saja tetapi juga kelas atas. Ini terlihat telah masuknya produk tahu dan tempe di pasar swalayan. Selain itu, tahu dan tempe termasuk lauk yang bergizi tinggi dan rendah kolesterol (Mukhoyaroh, 2015).

Salah satu faktor yang sangat penting untuk dikembangkan pada usaha kecil adalah masalah ergonomi. Kebanyakan berasumsi bahwa melakukan survey dan pengembangan ergonomis akan memakan biaya yang sangat besar. Namun jika diteliti lebih jauh dana yang dikeluarkan untuk survey dan pengembangan yang ergonomis lebih kecil jika dibandingkan dengan risiko yang terjadi dalam perajinan tanpa menggunakan prinsip ergonomi. Kelelahan perajin akibat terlalu lebarnya jarak antar tools di ruang kerja, waktu yang terbuang semakin banyak dan lainnya secara otomatis mengurangi produktivitas.

Mitra pada kegiatan pengabdian ini adalah usaha tempe Susini yang berada di kecamatan Medan Johor Provinsi Sumatera Utara. Banyak elemen kegiatan pada usaha tempe Susini tidak ergonomis yang berdampak kelelahan, produktivitas rendah serta ketidaknyamanan dalam bekerja. Usaha tempe Susini merupakan mitra utama dengan 4 orang perajin yang melakukan kegiatan pembuatan tempe dengan bahan baku $50 \mathrm{~kg}$ kacang kedelai setiap harinya. Proses produksi dimulai dari melakukan pemilihan kacang kedelai, pembersihan, perendaman, pemisahan kacang dan kulit ari, perebusan, pendinginan, pemberian ragi dan proses pembungkusan.

Pencucian kacang kedelai merupakan salah satu kegiatan yang cukup melelahkan karena perajin harus mengangkat ember berisi kacang kedelai dan air sehingga bobot ember cukup berat. Proses pencucian kacang kedelai dimulai dari tahapan penuangan $10 \mathrm{~kg}$ kacang kedelai ke dalam ember, pemberian air, pengadukan, mengangkat ember dan menuangkan air yang ada di dalam ember. Kegiatan pencucian kacang kedelai tersebut harus dilakukan perajin hingga bersih mencapai 5 kali. Dengan demikian untuk $50 \mathrm{~kg}$ kacang kedelai maka perajin harus melakukan proses pencucian kacang kedelai sebanyak 25 kali setiap harinya.

Selama ini perajin terbiasa mengangkat ember dengan cara membungkukkan bahu dan langsung mengangkat beban tersebut. Tulang punggung perajin sangat terbeban sehingga sering mengeluhkan sakit pada pinggang ketika bangun tidur sebagaimana dapat dilihat pada Gambar 1.1 (Jones, 2015).

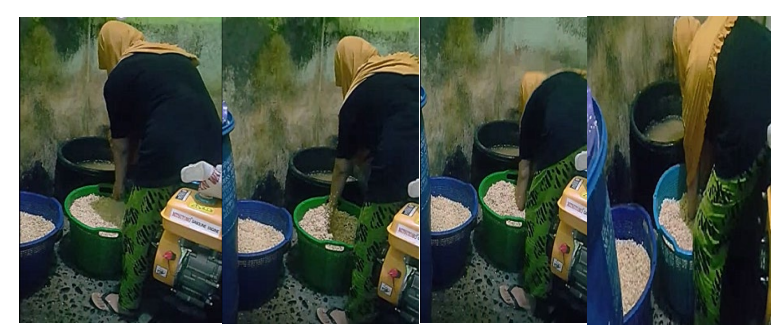

Gambar 1.1. Proses Pencucian Kacang Kedelai 
Risiko MSDs sangat tinggi pada saat proses produksi mencuci kacang kedelai sehingga sangat dibutuhkan solusi untuk memudahkan perajinan tersebut. Perajin pada bagian pencucian kacang kedelai mengeluhkan sakit pada pinggang dan kedua lengan karena kegiatan pencucian dilakukan secara manual. Hal ini yang menimbulkan keluhan sehingga terkadang perajin tidak bisa masuk karena mengalami cedera pada pinggang.

Keluhan perajin mulai dari sakit hingga sangat sakit dialami pada beberapa bagian tubuh. Beban kerja fisik secara berulang (repetitif) membuat otot-otot cepat berkonstraksi sehingga menimbulkan kelelahan dan rasa sakit. Keluhan tersebut mengindikasikan bahwa ada pembebanan yang tidak seimbang pada bagian tubuh perajin. Salah satu faktor yang menyebabkan keluhan muskuloskeletal adalah postur kerja yang tidak alamiah karena harus melakukan proses pencucian dengan postur kerja berdiri membungkuk secara terus menerus dan mengangkat beban yang berat. Proses pencucian kacang kedelai berlangsung di tempat yang sangat sempit (Gambar 1.2).

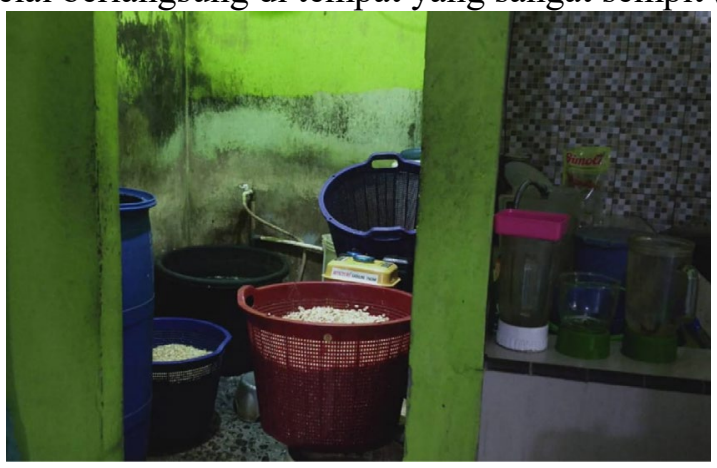

Gambar 1.2. Kondisi Tempat Pencucian

Proses pencucian yang dilakukan secara manual dengan bantuan alat yang sangat sederhana menyebabkan perajin cepat lelah dan mengalami sakit sehingga berdampak pada penurunan kualitas dan kuantitas tempe yang dihasilkan (Anizar, 2015).

\subsection{Rumusan Masalah}

Rumusan masalah pada kegiatan pengabdian ini adalah keluhan sakit yang dialami perajin tempe di bagian pinggang dan kedua lengan akibat proses pencucian kacang kedelai terus-menerus secara manual di ruang yang sangat sempit.

\subsection{Tujuan Kegiatan}

Mengatasi keluhan sakit yang dialami perajin tempe karena proses pencucian yang dilakukan secara manual di ruang yang sempit secara terus-menerus.

Tujuan khusus dari kegiatan pengabdian kepada masyarakat ini adalah,

1. Mendapatkan rancangan alat pencuci kacang kedelai mekanis dengan spesifikasi,

a. Dimensi alat yaitu tinggi $120 \mathrm{~cm}$, lebar $80 \mathrm{~cm}$ dan diameter tabung $100 \mathrm{~cm}$.

b. Alat pencuci kacang kedelai dilengkapi tuas penggerak di sisi kanan tabung sehingga memudahkan saat akan menggerakkan tabung untuk menuangkan isi nya.

c. Penyangga besi dilengkapi dengan kunci sehingga tabungnya dapat digerakkan untuk mengeluarkan kacang kedelai yang telah dicuci.

d. Alat pencuci kacang kedelai memiliki saringan yang dapat dibuka tutup sehingga saat tabung digerakkan untuk membuang air maka kacang kedelai yang berada di dalam tidak akan turut terbuang.

2. Memperluas areal pencucian kacang kedelai

3. Menerapkan pemakaian alat pencuci kacang kedelai mekanis oleh perajin tempe.

4. Mendapatkan waktu untuk melakukan pencucian kacang kedelai dengan alat pencuci kacang kedelai mekanis. 


\subsection{Manfaat dan Luaran}

Alat pencuci kacang kedelai mekanis menyebabkan proses pencucian kacang kedelai dapat dilakukan lebih cepat, kualitas pencucian bersih sempurna dan perajin dapat bekerja lebih nyaman karena hanya bertugas memasukkan dan mengeluarkan kacang kedelai ke dan dari dalam tabung, menuangkan air dari dalam tabung serta memindahkan kacang kedelai yang telah dicuci ke dalam wadah.

Perluasan areal pencucian kacang kedelai menyebabkan perajin tempe lebih leluasa dalam bekerja. Berbagai fasilitas kerja yang tadinya harus diletakkan di luar areal pencucian sudah dapat diletakkan di bagian dalam. Hal tersebut menyebabkan perajin lebih mudah untuk menjangkau fasilitas kerja seperti wadah untuk menuangkan hasil pencucian. Perajin membutuhkan waktu yang lebih singkat disebabkan jaraknya yang lebih dekat. Perluasan areal pencucian sudah mempertimbangkan peletakan alat pencuci kacang kedelai mekanis.

\section{METODE PELAKSANAAN}

Metode pelaksanaan pada kegiatan pengabdian ini melakukan pengamatan awal terhadap kegiatan proses produksi tempe secara keseluruhan. Kemudian melakukan diskusi dengan perajin tempe terkait pelaksanaan produksi selama ini. Tim menjelaskan solusi dan akan menerapkan solusi tersebut dengan mempertimbangkan masukan dari perajin (Gambar 2.1).

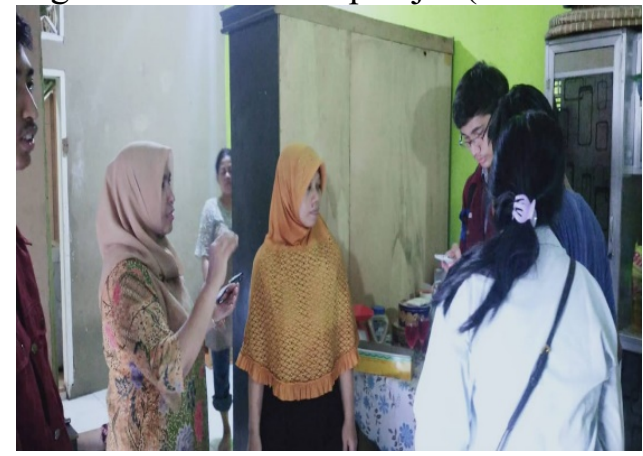

Gambar 2.1. Diskusi Perajin dengan Tim

Metode pelaksanaan pada kegiatan pengabdian secara terperinci adalah:

1. Sosialisasi metoda kerja yang lebih efektif terkait penggunaan alat pencuci kacang kedelai mekanis.

2. Pengukuran kapasitas produksi tempe yang baru dengan metode kerja dan fasilitas baru.

3. Sosialisasi pemakaian alat pencuci kacang kedelai mekanis serta metoda kerja dalam bentuk ceramah.

4. Pengukuran dimensi tubuh perajin tempe.

5. Rancang bangun alat pencuci kacang kedelai mekanis.

6. Pengadaan alat pencuci kacang kedelai mekanis.

7. Workshop alat pencuci kacang kedelai mekanis.

8. Pendampingan pemakaian alat pencuci kacang kedelai mekanis.

9. Perbaikan metoda kerja setelah penggunaan alat pencuci kacang kedelai mekanis.

\section{HASIL DAN PEMBAHASAN}

Perluasan areal pencucian kacang kedelai dilakukan untuk mengatasi tidak teraturnya fasilitas kerja yang digunakan. Perajin meletakkan wadah-wadah berisi kacang kedelai yang selesai digiling maupun yang telah selesai dicuci di bagian luar areal pencucian (Gambar 3.1). 


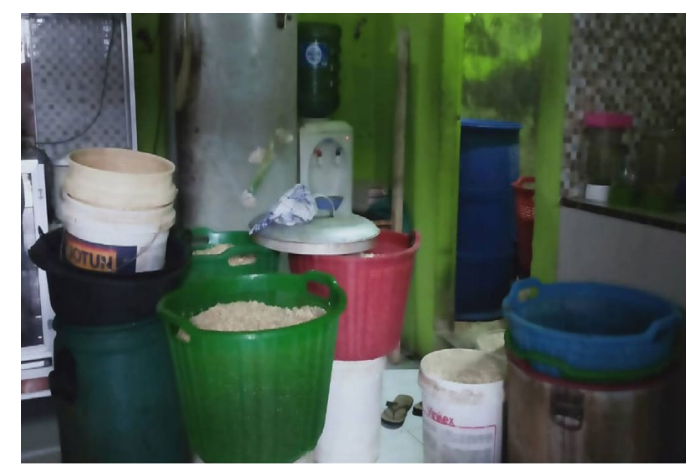

Gambar 3.1. Wadah Berisi Kacang Kedelai Giling

Areal pencucian kacang kedelai pada awalnya berukuran $2 \mathrm{~m}$ x 1,5m dan setelah dilakukan perluasan menjadi $3,8 \mathrm{~m} \times 1,5 \mathrm{~m}$. Perluasan ini menyebabkan fasilitas kerja yang digunakan seperti alat penggiling kacang kedelai, alat pencuci kacang kedelai dan wadah-wadah penampung kacang dapat ditempatkan di dalam areal pencuci kacang kedelai. Gambar 3.2 menampilkan kegiatan perluasan areal pencucian.

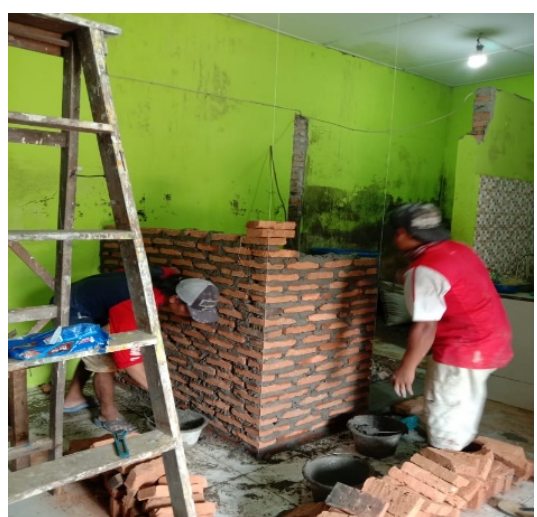

Gambar 3.2. Perluasan Areal Pencucian Kacang Kedelai

Kegiatan pembuatan tempe memiliki banyak kegiatan yang dilakukan secara manual terutama pada kegiatan pencucian. Fasilitas kerja yang digunakan sangat sederhana sehingga proses pembuatannya membutuhkan waktu yang lama. Tim pelaksana kegiatan pengabdian memutuskan untuk memberikan bantuan fasilitas kerja sehingga perajin dapat melakukan proses produksi tempe dalam waktu yang lebih singkat. Pengadaan fasilitas kerja meliputi alat pencuci kacang kedelai mekanis (Gambar 3.3).

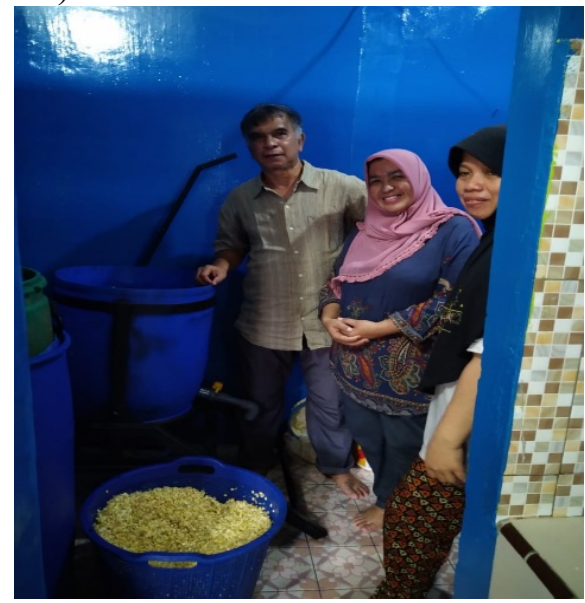

Gambar 3.3. Pencuci Kacang Kedelai Mekanis 
Alat pencuci kacang kedelai mekanis memiliki wadah yang terbuat dari fiberglass sehingga aman digunakan pada proses produksi kacang kedelai. Konsep kerja dari alat pencuci kacang kedelai mekanis adalah perajin tempe memasukkan kacang kedelai yang sudah digiling kemudian melakukan pengisian air dengan cara menghidupkan kran air. Ketika air sudah berada di atas permukaan kacang kedelai maka perajin dapat mematikan kran air dan kemudian menghidupkan alat pencuci dengan menekan tombol switch. Alat pencuci akan mulai bekerja dengan menggunakan pengaduk yang bergerak otomatis sesuai dengan waktu yang ditentukan perajin dan air bekas pencucian dibuang melalui saluran pembuangan dan kemudian memasukkan air lagi dari kran. Hal tersebut berulang sekali lagi hingga proses selesai dan kacang kedelai bersih serta siap dilanjutkan ke proses perebusan.

Gambar 3.4 menampilkan tim pengabdian beserta mahasiswa bersama dengan perajin tempe.

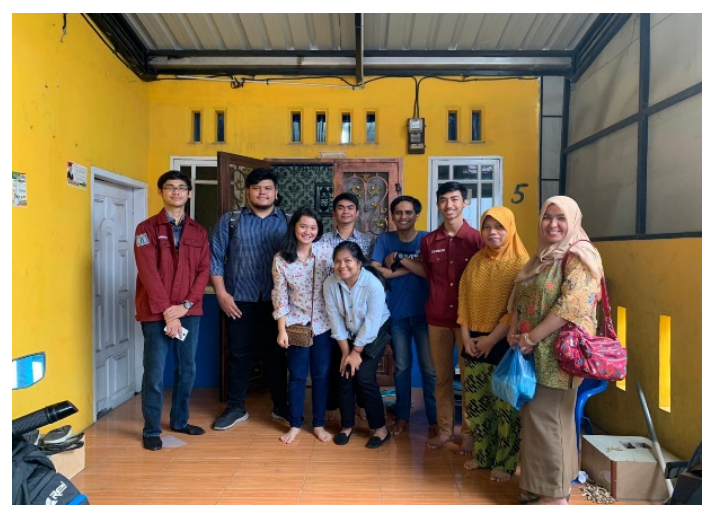

Gambar 3.4. Tim Pengabdian dengan Perajin Tempe

\section{KESIMPULAN}

Pengabdian yang dilakukan ini pada jangka pendek akan meningkatkan kualitas dan kuantitas tempe yang dihasilkan oleh perajin tempe. Sedangkan pada jangka panjang akan meningkatkan kinerja perajin sehingga akan meningkatkan tingkat pendapatan perajin tempe dengan bertambahnya tempe yang dihasilkan.

\section{UCAPAN TERIMAKASIH}

Ucapan terima kasih disampaikan kepada Rektor Universitas Sumatera Utara atas dana non PNBP USU TA 2019 yang diberikan dengan nomor kontrak 321/UN5.2.3.2.1/PPM/2019. Terima kasih juga disampaikan kepada mitra perajin tempe yang telah bersedia bekerja sama pada pelaksanaan kegiatan pengabdian ini.

\section{DAFTAR PUSTAKA}

Anizar. (2015). Analisis Desain Tojok Sebagai Alat Sortasi TBS Kelapa Sawit di Loading Ramp. Jurnal Teknik Industri, 149-154.

Jones, D. R. (2015). The Relationship Between Working Conditions and Musculoskeletal/

Ergonomic Disorders in a Manufacturing Facility - A Longitudinal Research Study. Procedia Manufacturing, 3(Ahfe), 4480-4484.https://doi.org/10.1016/j.promfg.2015.07.461 
Putra, A. H. 2016. Peran UMKM dalam Pembangunan dan Kesejahteraan Masyarakat Kabupaten Blora.

Fauzi, A. R., \& Puspitawati, M. D. (2018). Budidaya Tanaman Kedelai( Glycine max L.) Varietas Burangrang pada Lahan Kering, 1(1), 10-26. Retrieved from http://trilogi.ac.id/journal/ks/index.php/jbi/article/view/89/77

Jones, D. R. (2015). The Relationship Between Working Conditions and Musculoskeletal/Ergonomic Disorders in a Manufacturing Facility - A Longitudinal Research Study. Procedia Manufacturing, 3(Ahfe), 4480-4484. https://doi.org/10.1016/j.promfg.2015.07.461

Mukhoyaroh, H. (2015). Pengaruh Jenis Kedelai, Waktu Dan Suhu Pemeraman Terhadap Kandungan Protein Tempe Kedelai. Florea : Jurnal Biologi Dan Pembelajarannya, 2(2), 47-51. https://doi.org/10.25273/florea.v2i2.415

Nainggolan. (2014). Prospek Swasembada Kedelai Indonesia. Pangan, 23(1), 83-92.

Romli, M. S., Hutagaol, M. P., \& Priyarsono, D. S. (2016). Transformasi Struktural: Faktor-Faktor dan Pengaruhnya Terhadap Disparitas Pendapatan di Madura, 5(2), 45-67. 